\title{
Effects of Biodegradable Detergents in Morphological Parameters of Liver in Two Neotropical Fish Species (Prochilodus lineatus and Astyanax altiparanae)
}

\author{
Bruno Fiorelini Pereira1, Rebeca Mamede da Silva Alves², Anderson Luis Alves², \\ José Augusto Senhorini' ${ }^{3}$, Rita de Cássia Gimenes de Alcântara Rocha ${ }^{3}$, \\ Priscilla Hakime Scalize ${ }^{4}$, Dimítrius Leonardo Pitol ${ }^{4 *}$, Flávio Henrique Caetano ${ }^{1}$ \\ ${ }^{1}$ Universidade Estadual Paulista "Júlio de Mesquita Filho"-UNESP Campus de Rio Claro, São Paulo, Brazil \\ ${ }^{2}$ EMBRAPA, Palmas, Brazil \\ ${ }^{3}$ ICMBio/CEPTA, Pirassununga, Brazil \\ ${ }^{4}$ Faculdade de Odontologia de Ribeirão Preto, FORP/USP, Ribeirão Preto, Brazil \\ Email: dimitrius@forp.usp.br
}

Received 22 January 2014; revised 18 February 2014; accepted 20 April 2014

Copyright (C) 2014 by authors and Scientific Research Publishing Inc.

This work is licensed under the Creative Commons Attribution International License (CC BY).

http://creativecommons.org/licenses/by/4.0/

(c) (i) Open Access

\begin{abstract}
Indiscriminate disposal of residues of domestic and/or industrial origin in aquatic ecosystems resulting from urban activities causes concern about their effects on the fauna. Substances absorbed by animals, such as those cited above, are metabolized by the liver, as it is the main target organ of several pollutants and also exercises basic vital functions in the organism. For this reason the liver is used as the main and most reliable biomarker in environmental studies. Thus the objective of the present study was to identify hepatic alterations resulting from exposure to water contaminated by a few commercial brands of biodegradable detergents and their effects when present together with several other contaminants found in nature. For such, a solution of $1 \mathrm{ppm}$ of biodegradable detergents and water from an urban lake were tested on two widely distributed native Brazilian fish (Astyanax altiparanae and Prochilodus lineatus). Several alterations were found on the liver, including cytoplasm vacuolization, nuclear displacement, macrophage recruitment and reduced liver glycogen, showing a degenerative process in the liver of the fish, due to the action of contaminants.
\end{abstract}

\section{Keywords}

Liver, Fish, Detergent, Urban Lake, Pollution

\footnotetext{
${ }^{*}$ Corresponding author.
}

How to cite this paper: Pereira, B.F., et al. (2014) Effects of Biodegradable Detergents in Morphological Parameters of Liver in Two Neotropical Fish Species (Prochilodus lineatus and Astyanax altiparanae). Microscopy Research, 2, 39-49. 


\section{Introduction}

According to Langiado and Martinez [1] environmental pollution is becoming a problem of greater concern because it has damaged the quality of water. According to Sures et al. [2] aquatic biotas continue to suffer great chemical stress because of anthropogenic influence. Water pollution is commonly associated with the discharge of domestic, industrial or agricultural effluents. These practices generating a large quantity of residues and unloading it on water bodies are a cheap and efficient way to get rid of most of these contaminants [3]. There are hundreds of pollutants that affect the aquatic environment and their effects cause great concern. The main types of pollutants are metals, organic compounds (such as pesticides, PCBs, aliphatic hydrocarbonets, solvents, surfactantes, petroleum hydrocarbonets, organometalic compounds, gases, such as chlorine, anions, such as cyanets and sulphets, acids and alkaloids. This number grows annually, considering that new compounds and new formulations are synthesized [1] [3]. This concern was corroborated by Rodrigues \& Fanta [4] who reported that if on the one hand the human population prospers, on the other it raises environmental risks due to production of new chemical elements that accompany this growth.

Sánchez-Fortún et al. [5] reported that human activities are changing the biosphere and causing a crisis in biodiversity, because new substances are polluting water and causing environmental catastrophes in aquatic systems. This is a very important problem and basic research should be carried out to generate useful information for future predictions so that protection strategies for these environments can be elaborated [5]. According to Gernhofer et al. [6] aquatic environmental protection and restoration has attracted more attention over the last twenty years, so much so that new remedial and cleansing technologies have been developed and new legislation has been created to reduce contaminant emission. In industrialized countries, current problems related to the environment are correlated to toxin release in sublethal concentrations and their long term effects, which are difficult to detect [6].

Roy [7] reported that synthetic detergents are the most used substances in modern civilization, being used to prepare shampoos, domestic cleaning products and toothpaste and are now one of the largest sources of water pollution. According to Lal et al. [8] among the environmental contaminants, synthetic detergents released in aquatic ecosystems, with potential to affect the fauna and flora, are extremely important. Eleven fish and aquatic invertebrate species exposed to mixtures of alkyl benzene sulphonate, the active agent of detergent, in various environmental conditions and during different development stages, showed varied responses.

According to Fernandes et al. [9] the use of biomarkers has become an attractive and useful tool when monitoring environmental quality and the health of fish that inhabit polluted ecosystems. In this sense fish species are widely used as biological monitors of the variation in the levels of environmental pollutants [10].

Fernandes et al. [9] reported that the liver has vital functions for basic metabolism and is the organ that accounts for accumulation, biotransformation and excretion of contaminants in fish. Many xenobiotics and metals accumulate in the liver, so that its cells are exposed to a high level of chemical agents that may be present in the environment or in other organs of the fish [1]. Due to its function in metabolism and its sensitivity, the liver has stood out in toxicological studies related to contamination of various fish species by organic and inorganic chemical agents. Liver histopathology in fish is a monitoring tool that indicates the effects of stress agents in fish populations and is proposed as one of the most reliable biomarkers for use in studies of environmental impact on water animals [9].

Bearing in mind the current environmental context, the objective of the present study was to use the liver as biomarker in fish native to the Brazilian fauna, after exposure to urban pollutants, including biodegradable detergents.

\section{Methodology}

\subsection{Specimens}

To carry out the present study, 120 individuals were used, 60 of the Prochilodus lineatus species and 60 of the Astyanax altiparanae species. They were supplied by ICMBio/CEPTA-Pirassununga-SP-Brazil, after reproduction of their matrixes and the experiment started three months after hatching, for Prochilodus lineatus and four months after hatching for Astyanax altiparanae. These species were chosen because of their high commercial importance and, being used mainly as food and also because the genera are distributed throughout Brazil. 


\subsection{Experimentation}

The species were divided into three treatment groups containing 20 individuals each. The first, considered the control group, was exposed to proven pure water from the artesian well at UNESP-Campus de Rio Claro-SPBrazil; the second group was exposed to $1 \mathrm{ppm}$ dilution of commercial biodegradable detergents and the third to water from the Lago Azul-Rio Claro-SP, an urban lake and the end destination of sewage from surrounding residences, small industries and gas stations. All the experiment was replicated to confirm the results.

\subsection{Preparations for Histological Analyses}

Two samplings were made, the first after one month of exposure and the second after five months' exposure. Before euthanasia the animals were anesthetized with a benzocaine solution $(0.1 \mathrm{~g}$ benzocaine in $1 \mathrm{~mL}$ ethylic alcoholfor for every $100 \mathrm{~mL}$ of deionized water). After anesthesia, in each sampling six individuals were sacrificed per group. From each individual, liver fragments were removed and fixed in aqueous Bouin solution for 48 hours at $4^{\circ} \mathrm{C}$. The material was then buffered in sodium phosphate solution $\mathrm{pH}=7.4$, dehydrated at increasing alcohol concentrations, embedded in Leica historesin and sectioned with a Leica RM2245 microtome.

\subsection{Hepatocyte Morphology Analysis}

For this analysis five $6 \mu \mathrm{m}$ sections were obtained from each individual under study, which were submitted to the Hematoxylin and Eosine reaction according to [11]. This material was photographed with 40X objective lens on the Leica DM2000 microscope and the main morphological aspects of the hepatocytes were analyzed, such as nucleus position, presence of steatosis and nuclear and cytoplasmic vacuolization. In addition, the nuclei and the hepatocyte cytoplasm areas were analyzed. For such, 50 cells chosen randomly from each section obtained from the specimens under analysis were quantified, summing up to 250 cells per individual in each treatment. The measurements were made using ImageJ version $1.46 \mathrm{j}$ - segments were traced around the nuclei and cytoplasm to obtain the respective areas (Figure 1(A)). Only cells with clear nuclear and cytoplasmic limitations were analyzed, so there were no errors during quantification. From the data obtained the arithmetic mean was calculated for each one of the parameters analyzed in each individual of the three treatments and these means were compared statistically.

\subsection{Glycogen Quantification}

To analyze the glycogen five sections from each individual were analyzed after being submitted to PAS reaction according to [11]. Five fields of view were randomly photographed and analyzed for each section. They were always spots distant from large vessels, so that the greatest possible number of hepatocytes could be analyzed. Glycogen was isolated using an ImageJ plugin (Figure 1(B)), and the total area occupied by this reserve was quantified. Arithmetic means were obtained for each individual in each treatment, and compared statistically.

\subsection{Macrophage and Lysosome Identification}

For this analysis five $7 \mu \mathrm{m}$ sections were obtained from each individual and submitted to a technique adapted from Gomori [12]. From each of these sections, five fields of view were photographed and the macrophages were counted. At the end of the analysis, means for each individual in each treatment were generated, that were compared statistically.

\subsection{Statistical Analyzes}

The data obtained were analyzed using BioEstat 5.0. To identify variations among the results, the Shapiro-Wilk normality test was applied and later the ANOVA/Tukey or Kruskal-Wallis/Dunn test of variance was performed, depending whether the data in question were parametric or non-parametric.

\subsection{Chemical Analysis of the Water}

To better understand the results obtained, samples of the water used in the three treatments were sent to the Water Analysis Laboratory of the Department of Applied Geology at the Institute of Geosciences and Exact 

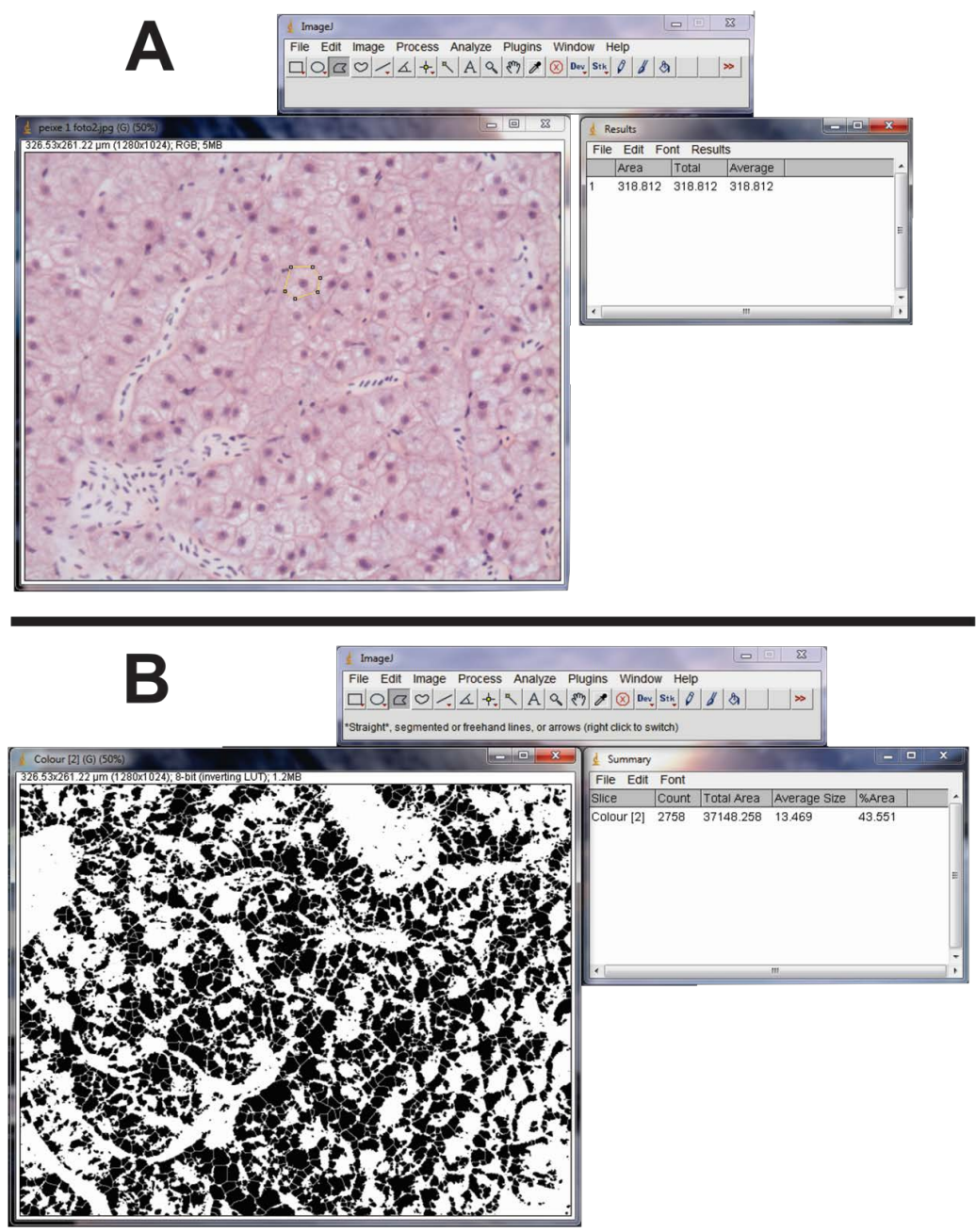

Figure 1. (A) methodology used to quantify the nucleus and cytoplasm's area, in the software Image J; (B) methodology for quantifying the area occupied by glycogen, in the software Image $\mathrm{J}$.

Sciences UNESP-Campus de Rio Claro. The analyses were carried out following the norms of the Standard Methods for the Examination of Water and Wastewater, for the parameters reported below:

Metals were determined by ICP-AES for the following elements: $\mathrm{Mg}, \mathrm{Ca}, \mathrm{Sr}, \mathrm{Ba}, \mathrm{Cr}(\mathrm{t}), \mathrm{Mn}, \mathrm{Fe}, \mathrm{Co}, \mathrm{Ni}, \mathrm{Cu}$, $\mathrm{Zn}, \mathrm{Cd}, \mathrm{Si}, \mathrm{P}(\mathrm{t})$ and $\mathrm{Pb}$. The anions: $\mathrm{F}^{-}, \mathrm{Cl}^{-}, \mathrm{NO}_{2}, \mathrm{NO}_{3}, \mathrm{PO}_{4}, \mathrm{SO}_{4}, \mathrm{ClO}_{2}^{-}$, acetate and oxalate plus the cations $\mathrm{Li}$, $\mathrm{Na}, \mathrm{NH}_{4}$ and $\mathrm{K}$ were determined by ionic chromatography. The $\mathrm{pH}$, conductivity, total alkalinity and carbonates were also analyzed by potentiometric titration.

Despite the fact that a constant detergent concentration was maintained, it was necessary to assess LAS concentration, linear akyl benzene sulphonate, the main active agent of domestic detergents. For such, chromatographic analyzes were carried out with HPLC Agilent Technologies 1200 series equipped with fluorescence detector at Global Análise \& Consultoria-São Carlos-SP-Brazil. The same test was carried out for water from the urban lake to identify the presence of LAS.

\section{Results}

\subsection{Survival}

There were no deaths during the experiment with Astyanax altiparanae, but during exposure to the urban lake $100 \%$ of the individuals of Prochilodus lineatus died after 35 days, so that only one period of exposure could be sampled. 


\subsection{Astyanax Altiparanae}

\subsubsection{Hepatocyte Morphology}

The hepatocytes observed in the control group had homogeneous cytoplasm and central nucleus. Both the treatment with detergent dilution and the treatment that contained water from the urban lake showed hepatocytes with nuclei displaced to the periphery, some with vacuolized nuclei or at the beginning of vacuolization process, and cytoplasms at the beginning of vacuolization process, for both experimental periods-these results are summarized on Table 1. Only the group exposed to detergent for five months showed rounded vesicles, characteristics of lipids, in this case indicating the pathology called moderate steatosis, (Figure 2(B), Figure 2(D) and Figure 2(F)).

Regarding the analysis of nucleus area and cytoplasm area, decrease in the nucleus area was observed only in the treatment with detergent after one month of experiment with $\mathrm{p}<0.01$ for the ANOVA/Tukey test, compared
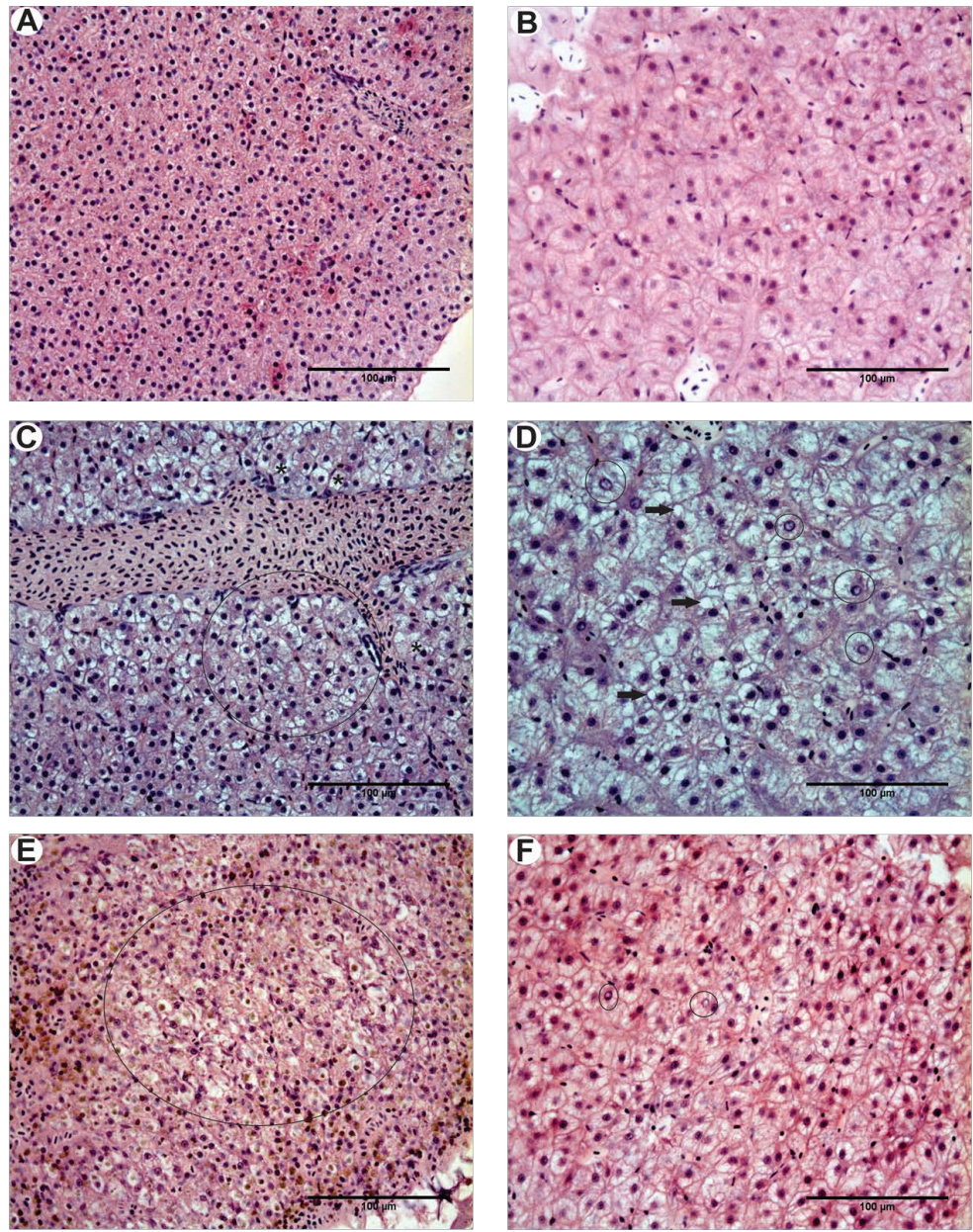

Figure 2. (A) and (B) Morphology of normal liver in P. lineatus and A. altiparanae respectively, note the homogeneity of the cytoplasm including the provision of the central nucleus, (C) Liver of $P$. lineatus after exposure to detergent, note the cytoplasmic degeneration (highlighted area) and cells with nuclei displaced to the periphery (*); (D) (A) Liver of A. altiparanae after exposure to the detergent note vacuolation of the cytoplasm present throughout the tissue and the presence of lipid deposits (arrow) and vacuolated nuclei (highlighted area), and-Liver of $P$. lineatus after exposure to water from the urban lake, note the cytoplasmic degeneration (highlighted area); (F)-(A) Liver of $A$. altiparanae after exposure to water from the urban lake, note the vacuolization of the cytoplasm present in the tissue and the presence of vacuolated nuclei (highlighted area). Technique: H-E. 
to the control. The data obtained for the cytoplasm showed decreased area in the detergent group in the two experimental periods, in the first month with $\mathrm{p}<0.01$ for the ANOVA/Tukeytest and in the fifth with $\mathrm{p}<0.05$ for the Kruskal-Wallis/Dunn test (Table 2).

\subsubsection{Glycogen Quantification}

The data obtained for the area occupied by glycogen showed that this energetic reserve decreased in the two treatments (Figure 3(B), Figure 3(D) and Figure 3(F)) throughout the experiment, with $\mathrm{p}<0.01$ for the ANOVA/ Tukey test in the first month and $\mathrm{p}<0.01$ for the Kruskal-Wallis/Dunn test in the fifth month (Table 2).

\subsubsection{Macrophage and Lysosome Analysis}

The macrophages were identified as large, dark brown and strongly colored markings, while the lysosomes were small and pale cytoplasmic dots. Regarding macrophage mobilization, significant recruitment of this cell type was identified in both contaminated treatments throughout the experiment, with $\mathrm{p}<0.01$ for the ANOVA/Tukey test (Table 2).

Lysosomes were abundant in the control group but their markings became scarce in the groups exposed to contaminated treatments, indicating possible inactivation of their enzymes, that are marked by the Gomori technique (see Section 3.2.2).

Table 1. Changes in the morphology of hepatocytes for the species Prochilodus lineatus and Astyanax altiparanae. $0=$ absent; + = uncommon ; ++ = common; +++ = very common; ++++ = extremely common.

\begin{tabular}{|c|c|c|c|c|c|c|c|c|c|c|c|}
\hline & \multicolumn{5}{|c|}{ P. lineatus } & \multicolumn{6}{|c|}{ A. altiparanae } \\
\hline & \multicolumn{2}{|c|}{ Control } & \multicolumn{2}{|c|}{ Detergent } & \multirow{2}{*}{$\begin{array}{c}\text { Lake } \\
\text { 1st } \\
\text { month }\end{array}$} & \multicolumn{2}{|c|}{ Control } & \multicolumn{2}{|c|}{ Detergent } & \multicolumn{2}{|c|}{ Urban Lake } \\
\hline & $\begin{array}{c}\text { 1st } \\
\text { month }\end{array}$ & $\begin{array}{l}\text { 5th } \\
\text { month }\end{array}$ & $\begin{array}{c}\text { 1st } \\
\text { month }\end{array}$ & $\begin{array}{l}\text { 5th } \\
\text { month }\end{array}$ & & $\begin{array}{c}\text { 1st } \\
\text { month }\end{array}$ & $\begin{array}{l}\text { 5th } \\
\text { month }\end{array}$ & $\begin{array}{c}\text { 1st } \\
\text { month }\end{array}$ & $\begin{array}{l}\text { 5th } \\
\text { month }\end{array}$ & $\begin{array}{c}\text { 1st } \\
\text { month }\end{array}$ & $\begin{array}{l}\text { 5th } \\
\text { month }\end{array}$ \\
\hline Cytoplasm Vacuolization & 0 & 0 & ++ & +++ & ++++ & 0 & 0 & +++ & ++++ & +++ & ++++ \\
\hline $\begin{array}{l}\text { Vacuolized Nuclei or the } \\
\text { Start of Vacuolization }\end{array}$ & 0 & 0 & ++ & ++ & + & 0 & 0 & + & +++ & +++ & ++ \\
\hline $\begin{array}{l}\text { Nuclei Displaced to the } \\
\text { Periphery }\end{array}$ & + & + & ++ & +++ & ++++ & + & + & +++ & ++++ & +++ & ++++ \\
\hline
\end{tabular}

0 = absent; + = uncommon; ++ = common; +++ = very common; ++++ = extremely common.

Table 2. Average of the area occupied by glycogen, the number of macrophages, and area of the nucleus and cytoplasm in the liver of fish species Astyanax altiparanae. Note the decrease in glycogen in the groups exposed to detergent and urban lake and the number carried in these same groups of macrophages compared to control throughout the experiment. It can also be observed the reduction in the areas of the nucleus and cytoplasm of the group exposed to detergent after one month of experiment and increased in the cytoplasm area in the fifth month of experiment in the same group.

\begin{tabular}{|c|c|c|c|c|c|c|c|c|c|c|}
\hline & \multicolumn{2}{|c|}{ Control } & \multicolumn{4}{|c|}{ Detergent } & \multicolumn{4}{|c|}{ Urban Lake } \\
\hline & \multirow{2}{*}{ 1st month } & \multirow{2}{*}{ 5th month } & \multicolumn{2}{|l|}{ 1st month } & \multicolumn{2}{|l|}{ 5th month } & \multicolumn{2}{|l|}{ 1st month } & \multicolumn{2}{|l|}{ 5th month } \\
\hline & & & Average & $\mathrm{p}$ & Average & $\mathrm{p}$ & Average & $\mathrm{p}$ & Average & $\mathrm{p}$ \\
\hline $\begin{array}{c}\text { Glycogen } \\
\left(\mu \mathrm{m}^{2}\right)\end{array}$ & $\begin{array}{c}40555.7302 \\
(\mathrm{SD}-3731.1076)\end{array}$ & $\begin{array}{c}49605.5152 \\
(\mathrm{SD}-1370.8603)\end{array}$ & $\begin{array}{c}27421.0391 \\
(\mathrm{SD}-1972.9582)\end{array}$ & $<0.01$ & $\begin{array}{c}16705.2130 \\
(S D-5828.0363)\end{array}$ & $<0.05$ & $\begin{array}{c}21082.4595 \\
(\mathrm{SD}-2120.4921)\end{array}$ & $<0.01$ & $\begin{array}{c}28899.4829 \\
(\mathrm{SD}-5832.5929)\end{array}$ & $<0.05$ \\
\hline $\begin{array}{c}\text { Number } \\
\text { of } \\
\text { Macrophages }\end{array}$ & $\begin{array}{c}23.1667 \\
(\mathrm{SD}-8.8638)\end{array}$ & $\begin{array}{c}22.6667 \\
(\mathrm{SD}-8.5713)\end{array}$ & $\begin{array}{c}88.0000 \\
(\mathrm{SD}-13.4759)\end{array}$ & $<0.01$ & $\begin{array}{c}113.0000 \\
(\mathrm{SD}-22.2711)\end{array}$ & $<0.01$ & $\begin{array}{c}123.8333 \\
(S D-17.5090)\end{array}$ & $<0.01$ & $\begin{array}{c}110.6667 \\
(\mathrm{SD}-27.1269)\end{array}$ & $<0.01$ \\
\hline $\begin{array}{c}\text { Nucleus } \\
\text { Area }\left(\mu^{2}\right)^{2}\end{array}$ & $\begin{array}{c}28.5039 \\
(S-5.2742)\end{array}$ & $\begin{array}{c}24.6425 \\
(\mathrm{~S}-4.8689)\end{array}$ & $\begin{array}{c}19.5232 \\
(\mathrm{~S}-2.4367)\end{array}$ & $<0.01$ & $\begin{array}{c}39.6102 \\
(\mathrm{~S}-13.3834)\end{array}$ & ns & $\begin{array}{c}26.5082 \\
(S-5.2514)\end{array}$ & ns & $\begin{array}{c}31.9745 \\
(S-9.9700)\end{array}$ & ns \\
\hline $\begin{array}{c}\text { Cytoplasm } \\
\text { Area } \\
\left(\mu \mathrm{m}^{2}\right)\end{array}$ & $\begin{array}{c}231.1537 \\
(\mathrm{SD}-58.5350)\end{array}$ & $\begin{array}{c}108.9280 \\
(\mathrm{SD}-11.2871)\end{array}$ & $\begin{array}{c}116.9762 \\
(\mathrm{SD}-35.1445)\end{array}$ & $<0.01$ & $\begin{array}{c}289.5170 \\
(\mathrm{SD}-55.9331)\end{array}$ & $<0.05$ & $\begin{array}{c}250.6489 \\
(\mathrm{SD}-50.7262)\end{array}$ & ns & $\begin{array}{c}176.0768 \\
(\mathrm{SD}-37.6191)\end{array}$ & ns \\
\hline
\end{tabular}

SD—standard deviation; P-Statistical results obtained in comparison with the control group; ns—no significant difference. 


\subsection{Prochilodus Lineatus}

\subsubsection{Hepatocyte Morphology}

The normal hepatocyte morphology was identical to that described previously. The same alterations were found as for Astyanax altiparanae, varying only on frequency (Figure 2(A), Figure 2(C) and Figure 2(E)) shown in Table 1.

The nucleus area did not show significant differences for any of the treatments. However, when the cytoplasm was analyzed, decrease in its area was detected in the group exposed to detergent after five month of experiment and increase in this parameter in the group exposed to the urban lake, with $\mathrm{p}<0.01$ for the ANOVA/Tukey test (Table 3).

\subsubsection{Glycogen Quantification}

The same pattern of glycogen reserve reduction found in Astyanax altiparanae was found in this species (Figure 3(A), Figure 3(C) and Figure 3(E)), with $\mathrm{p}<0.01$ for the ANOVA/Tukey test (Table 3).
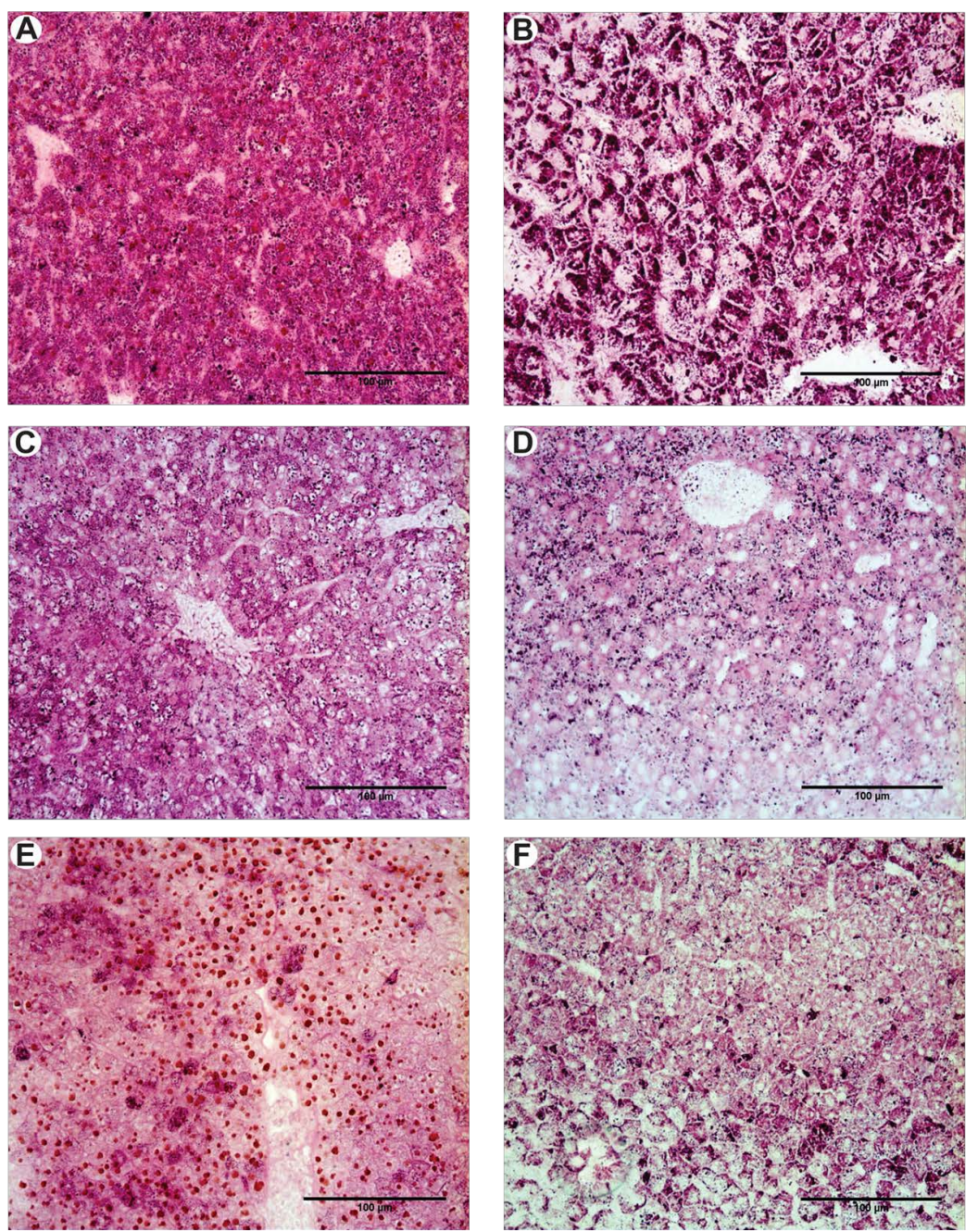

Figure 3. (A) and (B) Normal distribution of glycogen in the liver of $P$. lineatus and A. altiparanae respectively; (C) and (D) Distribution of glycogen in the liver of $P$. lineatus and A altiparanae respectively exposed to dilution of detergent; (E) and (F) Distribution of glycogen in the liver of $P$. lineatus and A altiparanae respectively exposed to water from an urban lake. Note the decrease in glycogen groups exposed pollutants in comparison with the control group. Technique: PAS. 
Table 3. Average of the area occupied by glycogen, the number of macrophages, and area of the nucleus and cytoplasm in the liver of fish species Prochilodus lineatus. Note the decrease in glycogen in the groups exposed to detergent and the urban lake and the number carried in these same groups of macrophages compared to control group throughout the experiment. It can also be observe a reduction in the area of the cytoplasm in the group exposed to the detergent after 5 months of experiment and the increase of the same parameter after the first month in the group exposed to lake water.

\begin{tabular}{|c|c|c|c|c|c|c|c|c|c|}
\hline & \multicolumn{2}{|c|}{ Control } & \multicolumn{4}{|c|}{ Detergent } & \multicolumn{3}{|c|}{ Urban Lake } \\
\hline & \multirow{2}{*}{ 1st month } & \multirow{2}{*}{ 5th month } & \multicolumn{2}{|l|}{ 1st month } & \multicolumn{2}{|l|}{ 5th month } & \multicolumn{2}{|l|}{ 1st month } & \multirow{2}{*}{$\begin{array}{l}\text { 5th month } \\
\text { Average } p\end{array}$} \\
\hline & & & Average & $\mathrm{p}$ & Average & $\mathrm{p}$ & Average & $\mathrm{p}$ & \\
\hline $\begin{array}{c}\text { Glycogen } \\
\left(\mu \mathrm{m}^{2}\right)\end{array}$ & $\begin{array}{c}53354,5903 \\
\text { (SD-2730.8369) }\end{array}$ & $\begin{array}{c}52666,9137 \\
\text { (SD-2642.6726) }\end{array}$ & $\begin{array}{c}22851,6008 \\
\text { (SD-2514.8979) }\end{array}$ & $<0.01$ & $\begin{array}{c}18306,7575 \\
\text { (SD-5808.3212) }\end{array}$ & $<0.01$ & $\begin{array}{c}14057,9496 \\
(\mathrm{SD}-1484.0154)\end{array}$ & $<0.01$ & \\
\hline $\begin{array}{c}\text { Number of } \\
\text { Macrophages }\end{array}$ & $\begin{array}{c}34,7143 \\
(\mathrm{SD}-8.0356)\end{array}$ & $\begin{array}{c}20,1667 \\
(\mathrm{SD}-6.6458)\end{array}$ & $\begin{array}{c}92,1667 \\
(\mathrm{SD}-13.0907)\end{array}$ & $<0.01$ & $\begin{array}{c}124,6667 \\
(S D-15.8072)\end{array}$ & $<0.01$ & $\begin{array}{c}115,6667 \\
\text { (SD-19.0333) }\end{array}$ & $<0.01$ & \\
\hline $\begin{array}{c}\text { Nucleus Area } \\
\left(\mu^{2}\right)\end{array}$ & $\begin{array}{c}23,4899 \\
(\mathrm{SD}-1.3556)\end{array}$ & $\begin{array}{c}19,0027 \\
(\mathrm{SD}-3.6779)\end{array}$ & $\begin{array}{c}21,4796 \\
(\mathrm{SD}-1.1278)\end{array}$ & ns & $\begin{array}{c}17,1805 \\
\text { (SD-5.6050) }\end{array}$ & ns & $\begin{array}{c}23,6953 \\
(\mathrm{SD}-4.2401)\end{array}$ & ns & \\
\hline $\begin{array}{c}\text { Cytoplasm } \\
\text { Area } \\
\left(\mu \mathbf{m}^{2}\right)\end{array}$ & $\begin{array}{c}195,3388 \\
(\mathrm{SD}-32.7083)\end{array}$ & $\begin{array}{c}134,6878 \\
(\mathrm{SD}-31.2936)\end{array}$ & $\begin{array}{c}210,9942 \\
(\mathrm{SD}-18.3051)\end{array}$ & ns & $\begin{array}{c}89,3400 \\
(\mathrm{SD}-25.1356)\end{array}$ & $<0.01$ & $\begin{array}{c}273,0362 \\
(S D-48.9931)\end{array}$ & $<0.01$ & \\
\hline
\end{tabular}

SD—standard deviation; P—Statistical results obtained in comparison with the control group; ns—no significant differences.

\subsubsection{Macrophage and Lysosome Analysis}

In Prochilodus lineatus there was also significant macrophage mobilization in the contaminated treatments throughout the experiment, with $\mathrm{p}<0.01$ for the ANOVA/Tukey test (Table 3). When the lysosomes were analyzed they were also abundant in the control, but became scarce in the group exposed to the urban lake and in the detergent group only after five months of experiment, unlike Astyanax altiparanae (Figure 4).

\subsection{Chemical Analysis of the Water}

The two treatments analyzed presented alkaline $\mathrm{pH}$ compared to the control (control 5.39; detergent 6.04; urban lake 7.17). This modification was due to an increase in $\mathrm{HCO}_{3}$ concentration in the samples (control: $1.2 \mathrm{mg} / \mathrm{L}$; detergent: $6.04 \mathrm{mg} / \mathrm{L}$; lake: $7.17 \mathrm{mg} / \mathrm{L}$ ). The group exposed to detergent also presented increases considered significant in the following parameters: $\mathrm{NO}_{2}^{-}$(control: $<0.04 \mathrm{mg} / \mathrm{L}$, detergent: $1.15 \mathrm{mg} / \mathrm{L}$ ) and $\mathrm{Ni}$ (control: < $0.010 \mathrm{mg} / \mathrm{L}$, detergent: $0.066 \mathrm{mg} / \mathrm{L}$ ), while the alterations in the treatment with urban lake water occurred with Na (control: <0.04 mg/L, lake: $16.7 \mathrm{mg} / \mathrm{L}$ ); $\mathrm{F}^{-}$(control: $0.25 \mathrm{mg} / \mathrm{L}$, lake: $0.40 \mathrm{mg} / \mathrm{L}$ ); $\mathrm{Cl}^{-}$(control: $8.56 \mathrm{mg} / \mathrm{L}$, lake: $16.7 \mathrm{mg} / \mathrm{L}$ ); $\mathrm{NO}_{2}^{-}$(control: <0.04 mg/L, lake: $0.86 \mathrm{mg} / \mathrm{L}$ ) and Fe (control: $0.021 \mathrm{mg} / \mathrm{L}$, lake: $0.16 \mathrm{mg} / \mathrm{L}$ ).

Regarding LAS concentration in diluted detergent, $0.375 \mathrm{mg} / \mathrm{l}$ of this surfactant was found in the sample. In the urban lake sample, $0.33 \mathrm{mg} / \mathrm{l}$ of this surfactant was found.

\section{Discussion}

According to Fernandes et al. [9] liver histopathology has been used as an environmental stress indicator because it is usually the endpoint of pollutants and its alterations depend on the contaminant's nature, its concentration and exposure time. The hepatic lesions were classified in groups and ranked according to their importance as an indicator of environmental contamination; non-neoplastic lesions, such as nuclear polymorphism, are considered initial reactions of exposure to toxic agents [9]. Hepatocellular necrosis is considered a response to severely contaminated environments, especially by metals [13] [14]. In studies performed by Maduenho \& Martinez [15] on Prochilodus lineatus species, two stages of liver degeneration were identified after exposure to diflubenzuron (DFB) insecticide and stage one was characterized by the presence of melanomacrophages, cell hypertrophy and nuclear and hepatocyte nuclei displacement to the periphery; the second stage presented nuclear degeneration, bile stagnation and pyknotic nuclei.

The present study demonstrated alterations such as cell hypertrophy, nuclei dislocated to the periphery, melanomacrophage aggregates reported by the authors quoted above. When compared with the study by Maduenho \& Martinez [15], even though the modifications found appeared similar, it was not possible to fit these data in either of their two stages, since in both species characteristics of the two stages were found simultaneously. 


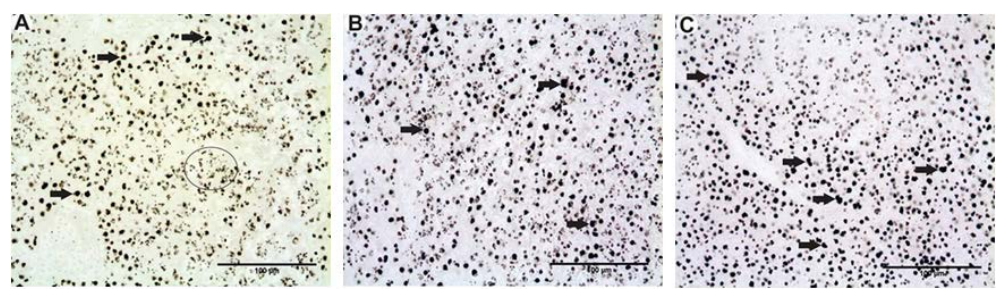

Figure 4. (A) Liver from the control group of the species $P$. lineatus, note the existence of some macrophages (arrow) and several lysosomes, which appear as small points (highlighted area). This same pattern occurs in control subjects in (A) altiparanae; (B) Liver from the group exposed to the detergent of the species $P$. lineatus, after 1 month of experiment, note the large number of macrophages (arrow) and the maintaining number of lysosomes; (D) The liver of es $P$. lineatus exposed to the urban lake water, note the large number of macrophages (arrow). This pattern held for the fifth month of exposure to detergent in this species and for the individuals exposed to contaminants in (A) altiparanae. The arrows indicate only a few macrophages (B) and (C) for the purpose of identification. Technique: Gomori.

Keeping in mind that that one of the species in our experiment was the same as used by the authors quoted above, we can emphasize that this classification may be specific for the contaminant tested by them or that the transition between these stages should still be defined and the time at which this process occurs may vary depending on the pollutant and the species under analysis. The results of the present study may be fitted more clearly in the identification given by Fernandes et al. [9] and the anomalies found can be inserted in the non-neoplastic group. Although the water analysis showed the presence of metals in both the contaminated treatments at higher concentrations than the control, necrotic hepatocytes were not found. This showed that these pollutants were at weaker dilutions, but that their presence, together with other substances, damaged the hepatic tissue.

According to Tekin-Özan [10] heavy metals are natural components of aquatic environments but their levels have risen due to industrial, agricultural and mineral mining waste. All these pollution sources affect the physiological characteristics of the water, sediments, biological components and consequently, fish stocks; bearing in mind that in order to maintain normal fish metabolism, the essential metals are absorbed from the water or sediments and can produce toxic effects when in excess Gaiser et al. [16] showed that hepatic cells exposed to aluminum in vitro for only two hours incorporated great part of the metal and stocked it in endocytic and secretory compartments [17]. Tekin-Özan \& Kir [17] in studies carried out on carp in a lake in Turkey demonstrated that water contamination by metals caused bioaccumulation of these elements in several tissues, and that the liver showed the highest levels of elements such as iron and [18] [19]. These data show that many of the studies with fish focus on heavy metals, but the action of these elements with other pollutants has not yet been well studied. However, they also show that many of the effects found in the present study result from the presence of dissolved metals.

Maduenho et al. [15] and Figueiredo-Fernandes et al. [9] studied tilapia (O. niloticus) exposed to copper and observed increase in hepatocyte nuclear size, similar to [20] in Brachydanio rerio, who also tested exposure to copper, suggesting that this alteration might indicate increase in metabolic activity resulting from detoxification. In the present study decrease was only found for the nucleus area, but these could not be classified as pyknotic because their shape was still defined and there was no condensing of the genetic material. This decrease in area may indicate the beginning of the process to form these inactive nuclei, that results in cell death. The same studies quoted above reported that generally increase in nuclear size is accompanied by cytoplasm dilation, both indicating high metallic activity. In the present study this type of alteration was identified but only accompanied by smaller nuclei, indicating that the cells may be in high detoxification activity, transitioning to the cell death process [1].

There are few studies on the effects of detergent in fish liver. [21] showed that Carassius auratus exposed to detergent can bioaccumulate surfactants in the liver. [22] demonstrated that Lates calcalifer exposed to LAS presented hepatocyte vacuolization, directly linked to delayed growth. The results presented in the present study showed much more serious alterations than those observed by [1], due to the fact that the effects of detergent and other contaminants, especially the metals, were enhanced when mixed as described by Brown et al. (1968). 
Lee et al. [23] demonstrated that Acipenser medirostris and Acipenser transmontanus fed with a methylmercury contaminated diet presented decreased glycogen levels and cytoplasm vacuolization, the last, due to abnormal lipid metabolism such as peroxidation. This metabolic variation may be related to failure in metabolic functions of excretion of substances in the liver and decrease in glucogenolysis, suggesting a greater energy demand to repair the damage caused by pollutants [23]. This showed that the data regarding glycogen accumulation obtained in the present study indicated an attempt by the organism to eliminate the contaminants and repair their effects. There are several reports of decrease in hepatic glycogen, but this is the first study to quantify numerically this effect.

According to Köhler et al. [24] the lysosome, which is acid in its interior, is the center of the endosomal-lysosomal system that is continuous with the Golgi derived vesicles, containing recently synthesized enzymes also called primary lysosome. Autophagic and heterophagic vacuoles fuse with the so-called primary lysosomes, forming the secondary lysosomes and later the so-called residual bodies that accumulate materials that cannot be digested. These authors reported, for Platichthys flesus collected in disturbed environments, that the liver presented decreased glycogen, accumulated cytoplasmic lipids, increase in the number of apoptotic cells and large macrophage aggregates; while lysosomes, were found to increase and decrease in number, due to lysosome fusion. Our data showed that the groups exposed to contaminants presented macrophage mobilization while the number of lysosomes decreased. This was probably not due to lysosomal fusion, but rather to the non-activation of its enzymes. This hypothesis was corroborated by [25] who reported that macrophage recruitment was directly linked to the presence of free radicals in the affected organ, and these are produced mainly during lipid peroxidation. The presence of a large quantity of macrophages indicated that there was a high rate of lipid metabolism and their existence was related to an excess of these molecules in the cell. The presence of a large quantity of lipids in the cell can result in inactivation of vacuoloar ATP-ase, responsible for lysosome acidification that inhibits cell digestion as observed in zebra fish by [26].

\section{Conclusion}

This study showed that analysis of the effects of surfactants on aquatic fauna should be taken into consideration, but studies should be focused on the action of these pollutants together with other contaminants, as it occurs in nature. It is also important that more precise analyses, such as quantification of glycogen and cytoplasm and nucleus area, should be adopted in environmental studies.

\section{Acknowledgements}

The authors are thankful to FAPESP process number: 2009/17118-9 for financial support and to ICMBio/ CEPTA-Institute Chico Mendes for providing the specimens used in this experiment.

\section{References}

[1] do C. Langiano, V. and Martinez, C.B. (2008) Toxicity and Effects of a Glyphosate-Based Herbicide on the Neotropical Fish Prochilodus Lineatus. Comparative Biochemistry and Physiology Part C: Pharmacology, Toxicology and Endocrinology, 147, 222-231. http://dx.doi.org/10.1016/j.cbpc.2007.09.009

[2] Sures, B., Steiner, W., Rydlo, M. and Taraschewski, H. (1999) Concentrations of 17 Elements in the Zebra Mussel (Dreissena polymorpha), in Different Tissues of Perch (Perca fluviatilis), and in Perch Intestinal Parasites (Acanthocephalus lucii) from the Subalpine Lake Mondsee, Austria. Environmental Toxicology and Chemistry, 18, 2574-2579. http://dx.doi.org/10.1002/etc.5620181126

[3] Mason, C.F. (1996) Biology of Freshwater Pollution. 3rd Edition, Longmann.

[4] Rodrigues, E.L. and Fanta, E. (1998) Liver Histopathology of the Fish Brachydanio rerio Hamilton-Buchman after Acute Exposure to Sublethal Levels of the Organophosphate Dimethoate 500. Revista Brasileira de Zoologia, 15, 441450. http://dx.doi.org/10.1590/S0101-81751998000200014

[5] Sánchez-Fortún, S., Marvá, F., Rouco, M., Costas, E. and López-Rodas, V. (2009) Toxic Effect and Adaptation in Scenedesmus Intermedius to Anthropogenic Chloramphenicol Contamination: Genetic Versus Physiological Mechanisms to Rapid Acquisition of Xenobiotic Resistance. Ecotoxicology, 18, 481-487. http://dx.doi.org/10.1007/s10646-009-0303-8

[6] Gernhöfer, M., Pawert, M., Schramm, M., Müller, E. and Triebskorn, R. (2001) Ultrastructural Biomarkers as Tools to Characterize the Health Status of Fish in Contaminated Streams. Journal of Aquatic Ecosystem Stress and Recovery, 8, 
241-260. http://dx.doi.org/10.1023/A:1012958804442

[7] Roy, D. (1998) Toxicity of an Anionic Detergent, Dodecylbenzene Sodium Sulfonate, to a Freshwater Fish, Rita Rita: Determination of L\&, Values by Different Methods. Ecotoxicology and Environmental Safety, 15, 186-194. http://dx.doi.org/10.1016/0147-6513(88)90071-1

[8] Lal, H., Misra, V., Viswanathan, P.N. and Murti, C.R.K. (1983) Comparative Studies on Ecotoxicology of Synthetic Detergents. Ecotoxicology and Environmental Safety, 7, 538-545. http://dx.doi.org/10.1016/0147-6513(83)90012-X

[9] Fernandes, C., Fontaínhas-Fernandes, A., Rocha, E. and Salgado, M.A. (2008) Monitoring Pollution in Esmoriz-Paramos Lagoon, Portugal: Liver Histological and Biochemical Effects in Liza Saliens. Environ Monit Assess, 145, 315322. http://dx.doi.org/10.1007/s10661-007-0041-4

[10] Tekin-Özan, S. and Kir, İ. (2007) Seasonal Variations of Heavy Metals in Some Organs of Carp (Cyprinus carpio L., 1758) from Beyşehir Lake (Turkey). Environmental Monitoring and Assessment, 138, 201-206. http://dx.doi.org/10.1007/s10661-007-9765-4

[11] Paulete, J. and Beçak, W. (1976) Técnicas de Citologia e Histologia. Livros Técnicos e Científicos, São Paulo, 2.

[12] Gomori, G. (1949) An Improved Histochemical Technic for Acid Phosphatase. Stain Technology, 25, 81-85.

[13] Schwaiger, J., Wanke, R., Adam, S., Pawert, M., Honnen, W. and Triebskorn, R. (1997) The Use of Histopathological Indicators to Evaluate Contaminant-Related Stress in Fish. Journal of Aquatic Ecosystem Stress Recovery, 6, 75-86. http://dx.doi.org/10.1023/A:1008212000208

[14] Olojo, E.A.A., Olurin, K.B., Mbaka, G. and Oluwemimo, A.D. (2005) Histopathology of the Gill and Liver Tissues of the African Catfish Clarias Gariepinus Exposed to Lead. African Journal of Biotechnology, 4, 117-122.

[15] Maduenho, L.P. and Martinez, C.B.R. (2008) Acute Effects of Diflubenzuron on the Neotropical Freshwater Fish Prochilodus lineatus. Comparative Biochemistry and Physiology Toxicology Pharmacology, 148, 265-272.

[16] Gaiser, B.K., Fernandes, T.F., Jepson, M.A., Lead, J.R., Tyler, C.R., Baalousha, M., Biswas, A., Britton, G.J., Cole, P.A., Johnston, B.D., Ju-Nam, Y., Rosenkranz, P., Scown, T.M. and Stone, V. (2011) Interspecies Comparisons on the Uptake and Toxicity of Silver and Cerium Dioxide Nanoparticles. Environmental Toxicology and Chemistry, 31, $144-154$.

[17] Tekin-Özan, S. and KIR, İ. (2007) Seasonal Variations of Heavy Metals in Some Organs of Carp (Cyprinus carpio L., 1758) from Beyşehir Lake (Turkey). Environmental Monitoring and Assessment, 138, 201-206. http://dx.doi.org/10.1007/s10661-007-9765-4

[18] Amundsen, P.A., Kashulin, N.A., Terentjev, P., Gjelland, K.Ø., Koroleva, I.M., Dauvalter, V.A., Sandimirov, S., Kashulin, A. and Knudsen, R. (2011) Heavy Metal Contents in Whitefish (Coregonus lavaretus) along a Pollution Gradient in a Subarctic Watercourse. Environmental Monitoring and Assessment, 182, 301-316.

[19] Padmini, E., Rani, M.U. and Geetha, B.V. (2008) Studies on Antioxidant Status in Mugil cephalus in Response to Heavy Metal Pollution at Ennore Estuary. Environmental Monitoring and Assessment, 155, 215-225. http://dx.doi.org/10.1007/s10661-008-0430-3

[20] Paris-Palacios, S., Biagianti-Risbourg, S. and Vernet, G. (2000) Biochemical and (Ultra)Structural Hepatic Perturbation of Brachydanio rerio (Teleostei, Cyprinidae) Exposed to Two Sublethal Concentrations of Copper Sulphate. Aquatic Toxicology, 50, 109-124. http://dx.doi.org/10.1016/S0166-445X(99)00090-9

[21] Tovell, P.W.A., Howes, D. and Newsome, C.S. (1975) Absorption, Metabolism and Excretion by Goldfish of the Anionic Detergent Sodium Lauryl Sulphate. Toxicology, 4, 17-29. http://dx.doi.org/10.1016/0300-483X(75)90018-9

[22] Rejeki, S., Desrina, D. and Mulyana, A.R. (2006) Chronic Affects of Surfactant Detergent (Linear Alkyl-Benzene Sulfonate/LAS) on the Growth and Survival Rate of Sea Bass (Lates calcalifer Bloch) Larvae. Journal of Coastal Development, Published Online.

[23] Lee, J.W., Kim, J.W., Nicola, D.R., Moniello, G. and Hung, S.S.O. (2012) Histopathological Alterations of Juvenile Green (Acipenser medirostris) and White Sturgeon (Acipenser transmontanus) Exposed to Graded Levels of Dietary Methylmercury. Aquatic Toxicology, 109, 90-99. http://dx.doi.org/10.1016/j.aquatox.2011.12.008

[24] Köhler, A., Wahl, E. and Söffker, K. (2002) Functional and Morphological Changes of Lysosomes as Prognostic Biomarkers of Toxic Liver Injury in a Marine Flatfish (Platichthys flesus (L.). Environmental Toxicology and Chemistry, 21, 2434-2444. http://dx.doi.org/10.1002/etc.5620211124

[25] Couillard, C.M. and Hodson, P.V. (1996) Pigmented Macrophage Aggregates: A Toxic Response in Fish Exposed to Bleached-Kraft Mill Effluent? Environmental Toxicology and Chemistry, 15, 1844-1854. http://dx.doi.org/10.1002/etc.5620151027

[26] Bibliowicz, J., Tittle, R.K. and Gross, J.M. (2011) Chapter 7-Toward a Better Understanding of Human Eye Disease Insights from the Zebrafish, Danio rerio. Progress in Molecular Biology and Translational Science, 100, 287-330. http://dx.doi.org/10.1016/B978-0-12-384878-9.00007-8 